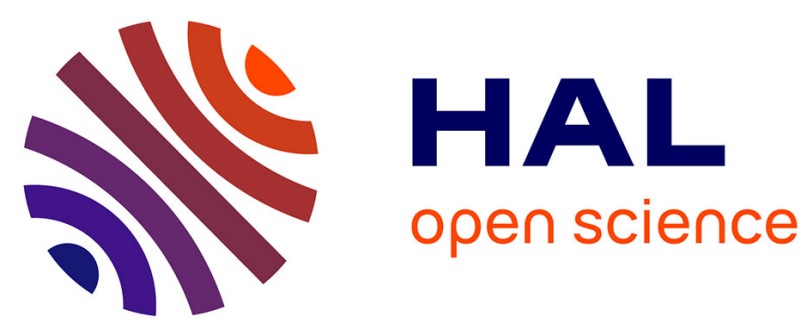

\title{
Impact of anatase and rutile titanium dioxide nanoparticles on uptake carriers and efflux pumps in Caco-2 gut epithelial cells
}

\author{
Marie Dorier, Emilie Brun, Giulia Veronesi, Frédérick Barreau, Karin \\ Pernet-Gallay, Caroline Desvergne, Thierry Rabilloud, Christine Carapito, \\ Nathalie Herlin, Marie Carrière
}

\section{To cite this version:}

Marie Dorier, Emilie Brun, Giulia Veronesi, Frédérick Barreau, Karin Pernet-Gallay, et al.. Impact of anatase and rutile titanium dioxide nanoparticles on uptake carriers and efflux pumps in Caco-2 gut epithelial cells. Nanoscale, 2015, 7, pp.7352-7360. 10.1039/C5NR00505A . hal-01157522

\author{
HAL Id: hal-01157522 \\ https://hal.science/hal-01157522
}

Submitted on 17 Nov 2015

HAL is a multi-disciplinary open access archive for the deposit and dissemination of scientific research documents, whether they are published or not. The documents may come from teaching and research institutions in France or abroad, or from public or private research centers.
L'archive ouverte pluridisciplinaire HAL, est destinée au dépôt et à la diffusion de documents scientifiques de niveau recherche, publiés ou non, émanant des établissements d'enseignement et de recherche français ou étrangers, des laboratoires publics ou privés. 


\section{Nanoscale}

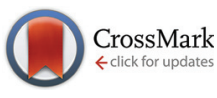

Cite this: Nanoscale, 2015, 7, 7352

Received 22nd January 2015, Accepted 24th March 2015

DOI: $10.1039 / c 5 n r 00505 a$

www.rsc.org/nanoscale

\section{Impact of anatase and rutile titanium dioxide nanoparticles on uptake carriers and efflux pumps in Caco-2 gut epithelial cells $\dagger$}

\author{
M. Dorier, ${ }^{a, b}$ E. Brun, ${ }^{c}$ G. Veronesi, ${ }^{d}$ F. Barreau, ${ }^{e}$ K. Pernet-Gallay, ${ }^{f, g}$ C. Desvergne, ${ }^{h}$ \\ T. Rabilloud, ${ }^{i}$ C. Carapito, ${ }^{j}$ N. Herlin-Boime ${ }^{k}$ and M. Carrière ${ }^{\star a, b}$
}

$\mathrm{TiO}_{2}$ microparticles are widely used in food products, where they are added as a white food colouring agent. This food additive contains a significant amount of nanoscale particles; still the impact of $\mathrm{TiO}_{2}$ nanoparticles $\left(\mathrm{TiO}_{2}\right.$-NPs) on gut cells is poorly documented. Our study aimed at evaluating the impact of rutile and anatase $\mathrm{TiO}_{2}-\mathrm{NPs}$ on the main functions of enterocytes, i.e. nutrient absorption driven by solute-liquid carriers (SLC transporters) and protection against other xenobiotics driven by efflux pumps from the ATP-binding cassette (ABC) family. We show that acute exposure of Caco-2 cells to both anatase $(12 \mathrm{~nm})$ and rutile $(20 \mathrm{~nm}) \mathrm{TiO}_{2}$-NPs induce early upregulation of a battery of efflux pumps and nutrient transporters. In addition they cause overproduction of reactive oxygen species and misbalance redox repair systems, without inducing cell mortality or DNA damage. Taken together, these data suggest that $\mathrm{TiO}_{2}$-NPs may increase the functionality of gut epithelial cells, particularly their property to form a protective barrier against exogenous toxicants and to absorb nutrients.

\section{Introduction}

Titanium dioxide particles are among the most produced mineral particles in the world; they are now introduced in a wide range of commercial products including food and daily

\footnotetext{
${ }^{a}$ Univ. Grenoble Alpes, INAC, SCIB, F-3800o Grenoble, France. Fax: +33 43878 5090; Tel: +334387803 28; E-mail: marie.carriere@cea.fr ${ }^{b}$ CEA, INAC, SCIB, F-38054 Grenoble, France ${ }^{c}$ UMR3299 CEA-CNRS, NIMBE, Laboratoire Structure et Dynamique par Résonance Magnétique (LSDRM), CEA Saclay, F-91191 Gif sur Yvette, France

${ }^{d}$ European Synchrotron Radiation Facility (ESRF), ID21 beamline, B.P. 220, F-38043 Grenoble, France

${ }^{e}$ INSERM, UMR 1043, Centre de Physiopathologie de Toulouse, Université de Toulouse, France

INSERM, U836, Grenoble, F-38042, France

${ }^{g}$ Univ. Grenoble Alpes, Grenoble Institut des Neurosciences, Grenoble, F-38042, France

${ }^{h}$ Univ. Grenoble Alpes, CEA, Nanosafety Platform, Medical Biology Laboratory (LBM), 17 rue des Martyrs, F-38054 Grenoble, France

${ }^{i}$ ProMD team, UMR CNRS 5249, Laboratoire de Chimie et Biologie des Métaux, UMR CNRS-CEA-Univ. Grenoble Alpes, F-38054 Grenoble, France

${ }^{j}$ Laboratoire de Spectrométrie de Masse Bio Organique (LSMBO), Université de Strasbourg, IPHC, CNRS UMR7178, Strasbourg, France

${ }^{k}$ URA2453 CEA-CNRS, NIMBE, LEDNA, CEA Saclay, F-91191 Gif sur Yvette, France $\dagger$ Electronic supplementary information (ESI) available: Nanoparticle physicochemical characterization: size distribution in exposure medium, as measured by DLS (Fig. S1), and X-ray diffraction patterns of A12 and R20 (Fig. S2); characterization of the protein corona on A12 and R20 (Table S1-S4 and experimental) See DOI: $10.1039 / \mathrm{c} 5$ nr00505a
}

hygiene products. ${ }^{1}$ Their production was evaluated at 5000 tons per year in 2006-2010 and was estimated to increase to 10000 tons per year in 2011-2014. ${ }^{2}$ Estimations based on daily consumption of $\mathrm{TiO}_{2}$-containing food lead to the conclusion that US children may be exposed to $1-2 \mathrm{mg} \mathrm{TiO}{ }_{2}$ per $\mathrm{kg}$ bw per day and US adults may be exposed to $0.2-0.7 \mathrm{mg} \mathrm{TiO}_{2}$ per $\mathrm{kg}$ bw per day. ${ }^{3}$ Another estimation reports exposure to $\sim 5 \mathrm{mg}$ $\mathrm{TiO}_{2}$ per person per day in the UK. ${ }^{4} \mathrm{TiO}_{2}$ food additive is mainly composed of micro-particles with diameter $>100 \mathrm{~nm}$, still about $36 \%$ of the particles are less than $100 \mathrm{~nm}$ in diameter, i.e. are nanoparticles $\left(\mathrm{TiO}_{2}-\mathrm{NPs}\right){ }^{3}$ The crystal phase of this food-grade $\mathrm{TiO}_{2}$ is either pure anatase or mixed anatase and rutile. ${ }^{5}$ As recently reviewed, ${ }^{6}$ the literature reporting their impact on gut cells is scarce.

Bio-distribution, toxico-kinetics and impact of $\mathrm{TiO}_{2}$-NPs administered per os to rodents depend on NP primary diameter, administration mode, as well as the age of animals. Adverse effects are observed in a variety of organs including the intestine, liver, kidneys, brain, immune cells and reproductive organs. ${ }^{7-9}$ In vitro, $\mathrm{TiO}_{2}$-NP toxicity studies have, up to now, focused on the most classical toxicological endpoints, i.e. cytotoxicity, genotoxicity, oxidative and pro-inflammatory potentials of NPs. They show that the impact of $\mathrm{TiO}_{2}$-NPs depends on their physico-chemical characteristics, their agglomeration state and the modalities of exposure, particularly the presence or absence of serum in exposure medium. Indeed, it is well documented that the presence $v s$. absence of 
serum, as well as the batch of serum modulates the internalization efficiency and adverse outcome of NPs. ${ }^{10,11}$ Mixed anatase/rutile $\mathrm{TiO}_{2}$-NPs, prepared in serum-free cell culture medium, induce cell mortality and DNA damage, but no oxidative stress in undifferentiated Caco- 2 cells. ${ }^{12,13}$ Conversely pure anatase $\mathrm{TiO}_{2}$-NPs, also prepared in serum-free medium, induce early production of reactive oxygen species (ROS) and cause the release of IL-8 chemochine, but no overt cytotoxicity. ${ }^{14}$ In differentiated Caco- 2 cells, acute exposure to mixed anatase/rutile $\mathrm{TiO}_{2}$-NPs in serum-free medium does not compromise the epithelium integrity and does not cause cell mortality. ${ }^{15}$ In this context, we previously showed that pure anatase $\mathrm{TiO}_{2}$-NPs accumulate but do not translocate through an epithelium of differentiated Caco- 2 cells, and do not cause overt cytotoxicity and epithelial structure disorganization. ${ }^{16}$ It is also well documented that the crystalline phase governs the biological impact of $\mathrm{TiO}_{2}$-NPs, both in vitro ${ }^{13,19}$ and in vivo. ${ }^{20}$ Anatase $\mathrm{TiO}_{2}$-NPs are considered to be more toxic than rutile NPs, particularly in the presence of light, due to a higher photo-catalytic activity. NPs with mixed anatase and rutile phases induce more severe cytotoxic and genotoxic damage than pure anatase or pure rutile NPs. This is possibly due to a synergistic effect of anatase and rutile phases in contact with each other. ${ }^{13}$

To go one step beyond these classical toxicological endpoints, in the present study we focused on $\mathrm{TiO}_{2}-\mathrm{NP}$ impact on the main functions of enterocytes, i.e. nutrient absorption and protection against xenobiotic. The rationale for testing such impact is that these two functions rely on the activity of a series of cell membrane transporters. Since we previously showed that $\mathrm{TiO}_{2}$-NPs adsorb on gut cell surface and accumulate in gut cells, ${ }^{16}$ we hypothesized that they may affect the function of transporters located on the cell membrane of enterocytes. Nutrient absorption is based on the activity of membrane transporters from the family of solute lipid carriers (SLC). The protective function relies on efflux pumps which are members of the family of ATP binding cassette (ABC) transporters, which contribute to the efflux of toxins from enterocytes and therefore function as gatekeepers against xenobiotic in the intestine. ${ }^{17}$

We thus examined the impact of $\mathrm{TiO}_{2}$-NPs on the expression of these cell membrane transporters on the Caco-2 cell line, which is considered as a good model of enterocytes, and has been used for long to study the transport and impact of pharmaceutical molecules through the gut. ${ }^{18}$ In parallel, we evaluated $\mathrm{TiO}_{2}$-NP cyto- and genotoxic impact, as well as the oxidative status of Caco- 2 cells exposed to these NPs. We compared the impact of fully characterized anatase and rutile $\mathrm{TiO}_{2}$-NPs with diameter 12 and $20 \mathrm{~nm}$, termed A12 and R20 (A standing for anatase and $\mathrm{R}$ for rutile; 12 standing for $12 \mathrm{~nm}$ mean diameter and 20 for $20 \mathrm{~nm}$ mean diameter).

\section{Results}

In most experiments, cells were exposed to $50 \mu \mathrm{g} \mathrm{mL} \mathrm{m}^{-1}$ of $\mathrm{TiO}_{2}-\mathrm{NP}$, which is a high concentration that can be considered as a worst case scenario. We chose to expose cells in serumcontaining medium since NPs entering the gut would improbably have a pristine surface, but would rather be coated by a dense protein corona.

\subsection{Nanoparticle physico-chemical characterization}

Suspensions of A12 and R20 were dispersed by sonication in water and diluted in exposure medium, i.e. complete cell culture medium (DMEM + 10\% FBS). Sonication in water efficiently dispersed A12 (see Fig. S1 $\dagger$ ) but not R20, even after long term high energy sonication. The $Z$-average of A12 was $132 \mathrm{~nm}$ while it was $>1000 \mathrm{~nm}$ for R20 (Table 1 and Fig. S1†). Upon dilution in exposure medium, the $Z$-average of A12 shifted to $320 \mathrm{~nm}$ and PdI increased to 0.290, i.e. the suspension slightly agglomerated (Table 1 and Fig. S1†). R20 remained agglomerated.

The zeta potential of both NP suspensions in exposure medium was negative but close to 0 , attesting for the instability of the suspensions (Table 1). A12 did not further agglomerate during the following $48 \mathrm{~h},{ }^{16}$ certainly because FBS induced the formation of a tightly-packed protein layer that prevented further agglomeration, as described by others. ${ }^{21,22}$ The proteins that adsorbed on the surface of A12 and R20 upon dilution in exposure medium are listed in Tables S1 and $\mathrm{S} 2 . \dagger$ These coronas were quite similar. Still 13 proteins out of 42 were contained in the corona of A12 but not of R20 (Table S3†) and 7 proteins out of 35 were part of the corona of R20 but not of A12 (Table S4 $\dagger$ ). Though, the non-overlapping proteins are among the minor contributors of the coronas with low unique peptide counts (for all A12 and R20 non-overlapping proteins, the number of unique peptides is lower than 4).

Therefore physico-chemical parameters that significantly differed between suspensions of A12 and R20 were their crystalline phase, their agglomeration state and, to a smaller extent, the composition of their protein corona.

Table 1 Physico-chemical characteristics of the $\mathrm{TiO}_{2}-\mathrm{NPs}^{\mathrm{a}}$

\begin{tabular}{lll}
\hline Parameter & A12 & R20 \\
\hline Crystalline phase & $95 \%$ anatase, & $90 \%$ rutile, \\
& $5 \%$ rutile & $10 \%$ anatase \\
Mean diameter (TEM) $(\mathrm{nm})$ & $12 \pm 3$ & $22 \pm 4$ \\
SSA $\left(\mathrm{m}^{2} \mathrm{~g}^{-1}\right)$ & $82 \pm 3 \mathrm{~m}^{2} \mathrm{~g}^{-1}$ & $73 \pm 5 \mathrm{~m}^{2} \mathrm{~g}^{-1}$ \\
$Z$-Average in water $(\mathrm{nm})$ & $132 \pm 1$ & $>1000$ \\
& $(\mathrm{PdI}=0.188)$ & $(\mathrm{PdI}>0.8)$ \\
$\zeta$ in water $(\mathrm{mV})$ & $-20.0 \pm 0.6$ & $-19.5 \pm 0.9$ \\
PZC & 6.4 & 5.6 \\
$Z$-Average in expo. medium $(\mathrm{nm})$ & 320 & $>1000$ \\
& $(\mathrm{PdI}=0.290)$ & $(\mathrm{PdI}>0.8)$ \\
$\zeta$ in expo. medium $(\mathrm{mV})$ & $-10.8 \pm 0.6$ & $-11.7 \pm 0.8$
\end{tabular}

${ }^{a}$ Primary particle diameter (mean diameter) was measured on transmission electron microscopy (TEM) images. SSA: specific surface area. Z-Average: measurement of NP hydrodynamic diameter (in number), obtained by photon correlation spectroscopy (PCS). PdI: polydispersity index. $\zeta$ : zeta potential. PZC: point of zero charge. Expo. medium: exposure medium. 


\subsection{Nanoparticle cellular accumulation and distribution}

Ti content in cells exposed to A12 and R20, reflecting intracellular accumulation as well as cell membrane adsorption, was measured by ICP-MS after exposure of Caco- 2 cells to $50 \mu \mathrm{g} \mathrm{mL} \mathrm{m}^{-1}$ of these NPs. Ti content in cells exposed to R20 was 3 to 4 times as high as in cells exposed to A12 (Fig. 1). It increased between $6 \mathrm{~h}$ and $24 \mathrm{~h}$ of exposure; then it slightly decreased between $24 \mathrm{~h}$ and $48 \mathrm{~h}$ (Fig. 1). In the same exposure conditions, their intracellular distribution was observed by TEM (Fig. 2A and B) and micro-X-ray fluorescence ( $\mu \mathrm{XRF}$ ) (Fig. 2C and D). ${ }^{16,23}$ Electron-dense agglomerates were observed in cells exposed to A12 (Fig. 2A) and R20 (Fig. 2B). They located close to the apical pole, entrapped in large cytoplasmic compartments and were identified as being composed of Ti (Fig. 2C and D).

\subsection{Cytotoxicity, genotoxicity, cell redox status}

We already reported the absence of overt cytotoxicity, epithelial integrity alteration and para-cellular and trans-cellular permeability properties in differentiated Caco- 2 cells exposed to A12. ${ }^{16}$ In the present study, neither A12 nor R20 induced overt cell mortality of undifferentiated Caco-2 cells (Fig. 3A), or any DNA strand breaks or alkali-labile sites in the comet assay (Fig. 3B). In contrast, we monitored a significant production of ROS in cells exposed to $50 \mu \mathrm{g} \mathrm{mL} \mathrm{L}^{-1}$ of either A12 or R20. This increased production of ROS was significant at $6 \mathrm{~h}$ of exposure and did not further increase at $48 \mathrm{~h}$ post-exposure (Fig. 3C). At $48 \mathrm{~h}$ post-exposure, ROS content was significantly higher in cells exposed to R20 than in cells exposed to A12 (Fig. 3C). A12 and R20 also significantly increased cellular glutathione content (Fig. 3D). Although the activity of superoxide dismu-

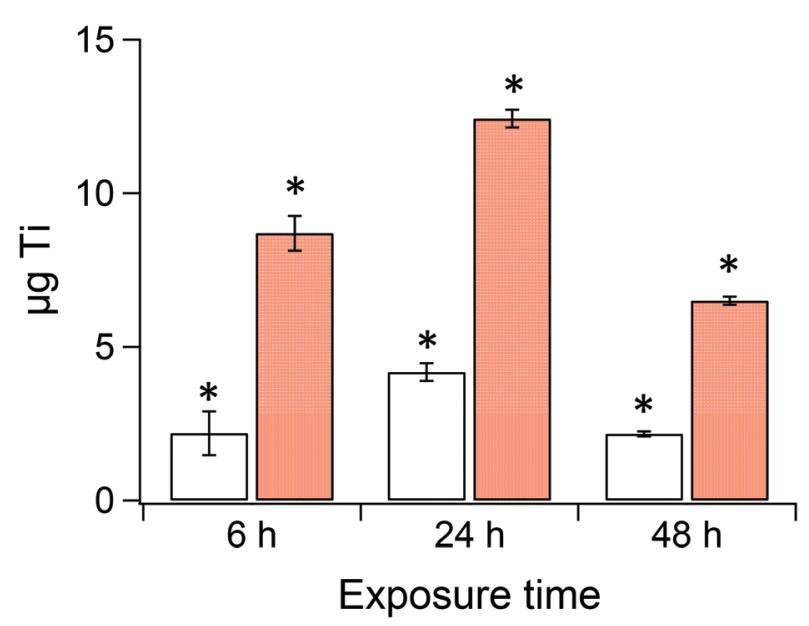

Fig. $1 \mathrm{TiO}_{2}-\mathrm{NP}$ accumulation in Caco-2 cells. Intracellular content of $\mathrm{Ti}$ was measured by ICP-MS in Caco- 2 cells exposed to $50 \mu \mathrm{g} \mathrm{mL}^{-1}$ of $\mathrm{A} 12$ (white bars) or R20 (red bars) for 6, 24 or $48 \mathrm{~h}$. Cells were then harvested, live cells were counted and Ti content was measured in 360000 cells ( $\mu \mathrm{g} \mathrm{Ti}$ ). Presented data are expressed as mean of three independent replicates per condition \pm standard deviation; statistical significance of exposed cells vs. control cells, ${ }^{*} p<0.05$, Mann-Whitney $U$-test.
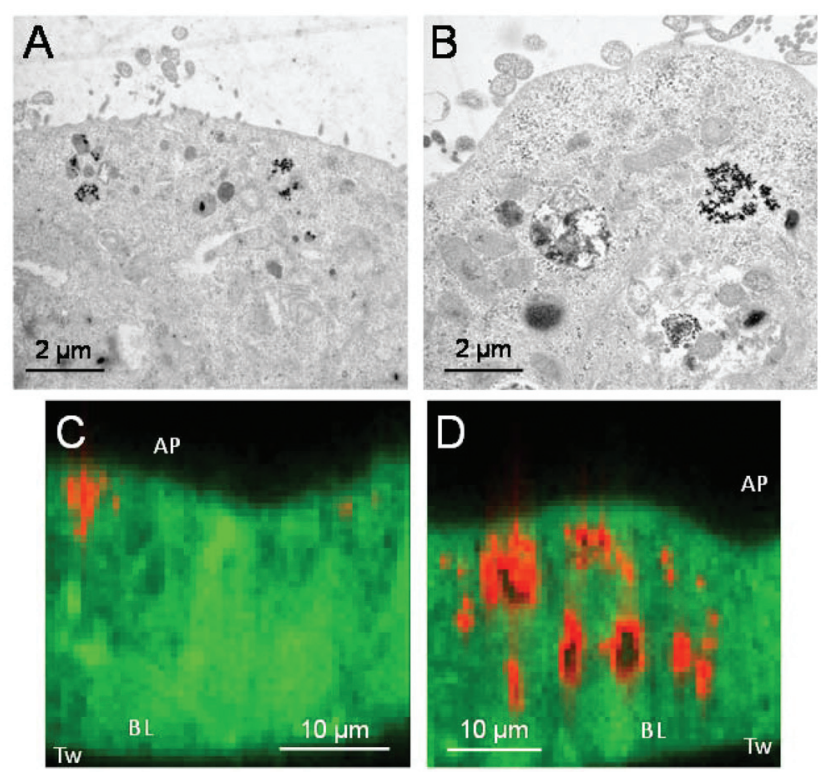

Fig. 2 TEM and $\mu$ XRF images of $\mathrm{TiO}_{2}-\mathrm{NPs}$ accumulated in Caco-2 cells. TEM observation of Caco-2 cells exposed to $50 \mu \mathrm{g} \mathrm{mL} \mathrm{m}^{-1}$ of $\mathrm{A} 12$ (A) or R20 for $24 \mathrm{~h}$ (B). Micro-XRF imaging of Caco-2 cells exposed to $50 \mu \mathrm{g}$ $\mathrm{mL}^{-1}$ of $\mathrm{A} 12$ (C) or R20 (D) for $48 \mathrm{~h}$. Phosphorous (P) et titanium (Ti) distributions are mapped in green and red, respectively. AP: apical pole; $B L$ : basolateral pole; Tw: transwell membrane.
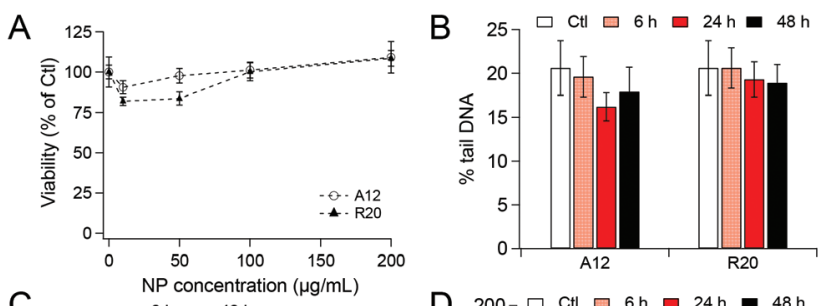

C
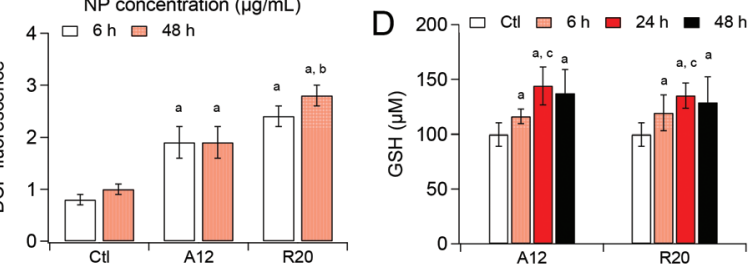

$\mathrm{E}$
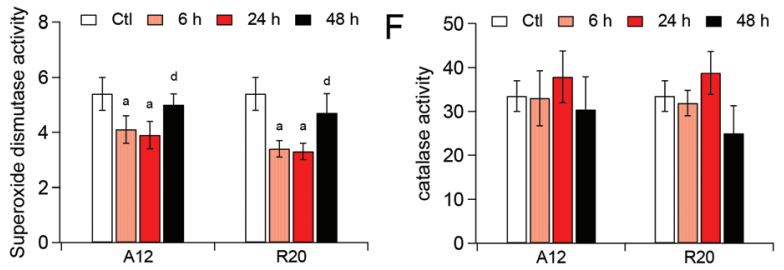

Fig. 3 Cell viability was probed with the MTT assay (A) after a $24 \mathrm{~h}$ exposure at NP concentrations ranging from 0 to $200 \mathrm{\mu g} \mathrm{mL}^{-1}$. Genotoxicity of $\mathrm{TiO}_{2}-\mathrm{NPs}\left(50 \mu \mathrm{g} \mathrm{mL}{ }^{-1}\right)$ assessed via the alkaline comet assay (B). Reactive oxygen species (C) and reduced glutathione (GSH, D) contents, superoxide dismutase (E) and catalase (F) activity modulations, measured after exposure for $6 \mathrm{~h}, 24 \mathrm{~h}$ or $48 \mathrm{~h}$ to $50 \mu \mathrm{g} \mathrm{mL}^{-1}$ of $\mathrm{A} 12$ and R20. Results are average of 3 independent experiments \pm standard deviation except for comet assay where they are median \pm standard error of the mean. ${ }^{*} p<0.05$; Mann-Whitney $U$-test; a: control cells vs. exposed cells; b: A12 vs. R20, 48 h; c: 6 h vs. 24 h; d: 24 h vs. 48 h. 
tase was significantly reduced (Fig. 3E), we did not observe any modulation of catalase activity (Fig. 3F). Altogether, these data evidenced that exposure to NPs did not alter cell viability, but disturbed the redox balance of exposed cells.

\subsection{Impact of $\mathrm{TiO}_{2}$-NPs on nutrient uptake transporters and xenobiotic efflux pumps}

$\mathrm{TiO}_{2}$-NPs are accumulated in Caco-2 cells, but also adsorbed on cell membranes. This interaction may lead to impairment of membrane functions, which for enterocytes are nutrient uptake through the SLC transporter family, and protection against drugs and xenobiotic through efflux pumps from the ABC transporter family. Differentiation is essential for membrane transporters to reach their final location, i.e. either the apical or the basolateral pole of the cell. For this experiment we thus used differentiated Caco- 2 cells, i.e. cells grown 21 days post-confluence.

We monitored significant, although moderate, modulations of the expression of genes encoding these two families of transporters (see Table 2 for detail) in Caco- 2 cells exposed for $6 \mathrm{~h}$ or $48 \mathrm{~h}$ to $50 \mu \mathrm{g} \mathrm{mL} \mathrm{m}^{-1}$ of $\mathrm{A} 12$ (Fig. $4 \mathrm{~A}$ and B) and R20 (Fig. 4C and D). We generally observed early up-regulation of

Table 2 Genes encoding key transport proteins that were analysed by RT-qPCR

\begin{tabular}{|c|c|}
\hline Gene identification & Encoded protein name and function \\
\hline CAV1, CAV2 & Caveolin 1 and 2 , caveolae proteins \\
\hline LRP1 & Low-density lipoprotein receptor-related protein 1 , endocytic receptor \\
\hline FCGRT & Uptake of IgG through intestinal epithelial cells \\
\hline INSR & Insulin receptor \\
\hline TFRC & Transferrin receptor \\
\hline SLC2A1 & Glucose transporter \\
\hline SLC15A1, 15A2 & Proton-coupled peptide transporters \\
\hline SLC7A7, 7A8 & Cationic amino-acid transporters \\
\hline SLCO1A2 & Sodium-dependent transporter of organic ions \\
\hline MDR1 = ABCB1 & P-glycoprotein, drug and xenobiotic efflux, broad substrate specificity \\
\hline MRP1 = ABCC1 & Multidrug resistance protein 1 , efflux of organic anions and glutathione-conjugated compounds \\
\hline $\mathrm{MRP} 2=\mathrm{ABCC} 2$ & Multidrug resistance protein 2, efflux of organic anions \\
\hline $\mathrm{MRP} 4=\mathrm{ABCC} 4$ & Multidrug resistance protein 4 , efflux of organic anions, undetermined specific function \\
\hline MRP5 = ABCC5 & Multidrug resistance protein 5 , efflux of cyclic nucleotides \\
\hline MRP6 = ABCC6 & Multidrug resistance protein 6 , efflux of organic anions, glutathione-conjugated compounds \\
\hline $\mathrm{BCRP}=\mathrm{ABCG} 2$ & Breast cancer resistance protein \\
\hline
\end{tabular}
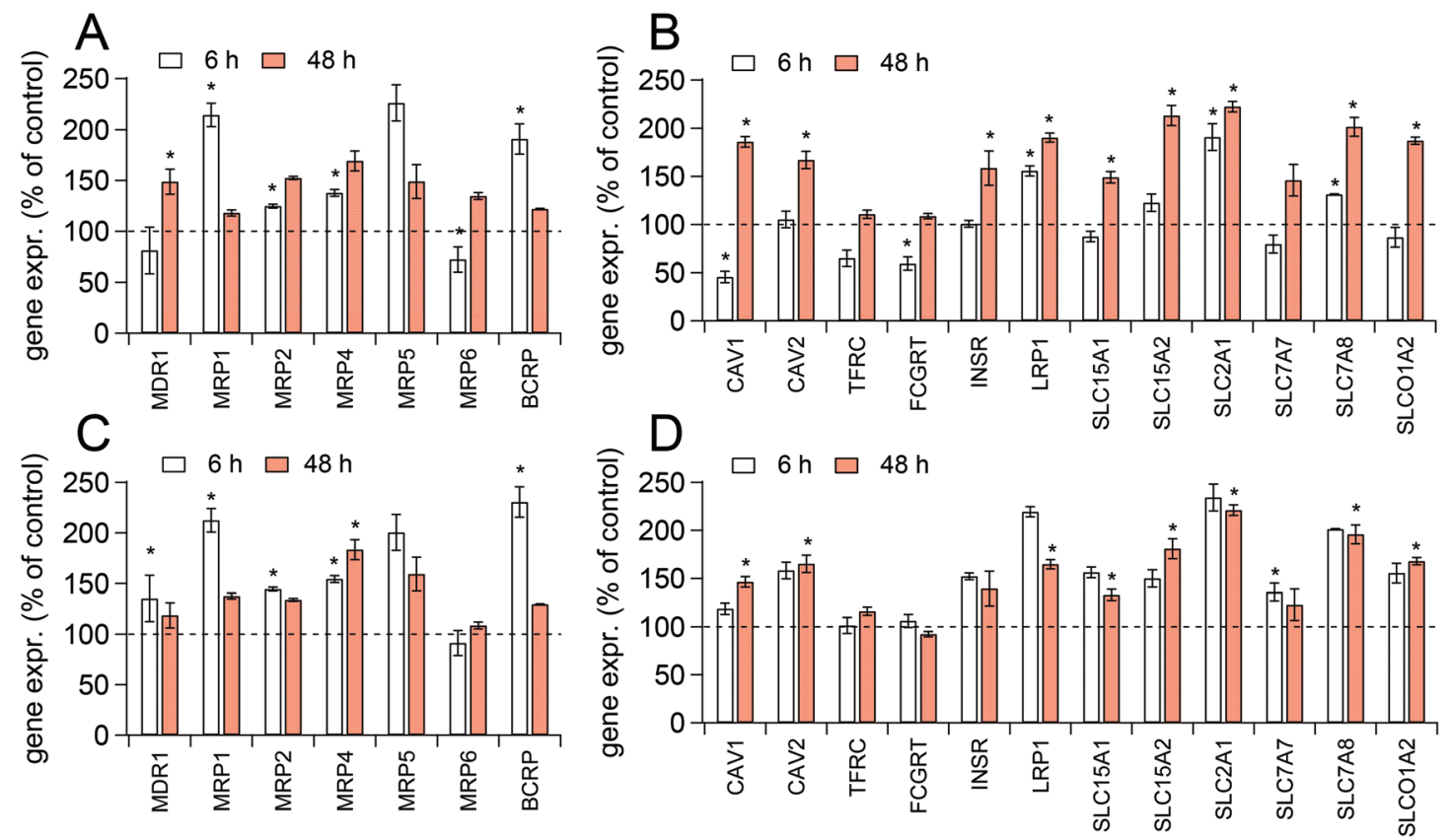

Fig. 4 mRNA expression in Caco-2 cells exposed to $\mathrm{TiO}_{2}-\mathrm{NPs}$. mRNA expression of ABC efflux pumps and nutrient transporters, quantified by RTqPCR after $6 \mathrm{~h}$ or $48 \mathrm{~h}$ of exposure to $50 \mu \mathrm{g} \mathrm{mL} \mathrm{L}^{-1}$ of A12 (A-B) and R20 (C-D). Results are expressed as fold change in NP-exposed cells as compared to unexposed cells. They represent mean of 3 replicates \pm standard deviation; control vs. exposed cells, ${ }^{*} p<0.05$, Mann-Whitney $U$-test. 
ABC transporter-encoding genes: MRP1, MRP2, MRP4 and BCRP were up-regulated in cells exposed for $6 \mathrm{~h}$ to $\mathrm{A} 12$ (Fig. 4A) and R20 (Fig. 4C). Moreover, at $6 \mathrm{~h}$ of exposure, MDR1 was upregulated by R20 only and MRP6 was down-regulated by $\mathrm{A} 12$ only. These modulations were transient since after $48 \mathrm{~h}$ of exposure the only significant changes in gene expression was up-regulation of MDR1 in cells exposed to A12 and up-regulation of MRP4 in cells exposed to R20.

In opposition to the early up-regulation of efflux pumps, we observed late modulation of the expression of genes encoding SLC transporters, which was also rather up-regulation (Fig. 4B and $4 \mathrm{D}$ ). After $48 \mathrm{~h}$ of exposure, both A12 and R20 induced upregulation of SLC2A1 (GLUT-1) and LRP1, encoding transporters involved in the hexose/lipid homeostasis processes. A12 and R20 also induced up-regulation of SLC7A8, SLC15A1 and SLC15A2 encoding proton-coupled PepT1 and PepT2 peptide transporters, respectively, involved in the amino acid and peptide absorption processes. Finally they both induced upregulation of SLCO1A2, encoding the OATP1A2 transporter, implicated in the transport of a variety of organic ions including drugs and xenobiotic. Furthermore, A12 and R20 induced up-regulation of genes encoding two caveolins (CAV1 and CAV2). The insulin receptor, INRS, was upregulated in cells exposed for 48 h to A12 only. LRP1, SLC2A1 and SLC7A8 were also upregulated by A12 after $6 \mathrm{~h}$ of exposure, while CAV1 and FCGRT, encoding an IgG transporter, were down-regulated by A12 after 6 h of exposure. Finally, SLC7A7 was upregulated in cells exposed for $6 \mathrm{~h}$ to R20.

At the protein level, expressions of MDR1 and BCRP were significantly reduced in Caco- 2 cells exposed $6 \mathrm{~h}$ to A12 and R20, and expression of MDR1, MRP1, MRP2 and BCRP were significantly increased after $48 \mathrm{~h}$ of exposure to both $\mathrm{A} 12$ (Fig. 5A) and R20 (Fig. 5B).

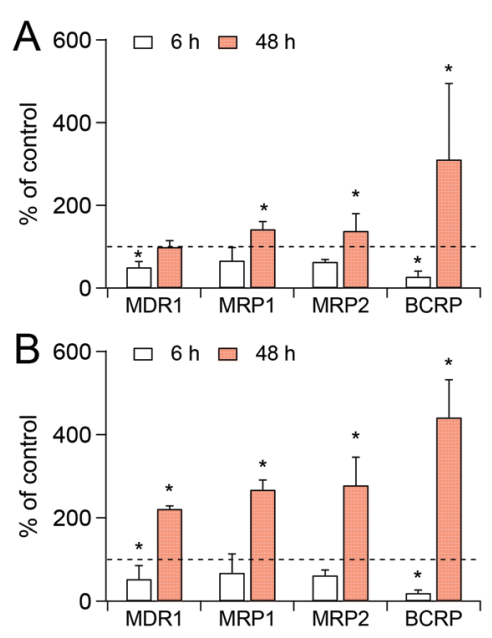

Fig. 5 Protein expression in Caco-2 cells exposed to $\mathrm{TiO}_{2}$-NPs. Protein expression of MDR1, MRP1, MRP2 and BCRP, quantified by western blot after $6 \mathrm{~h}$ or $48 \mathrm{~h}$ of exposure of Caco-2 cells to $50 \mu \mathrm{g} \mathrm{mL}^{-1}$ of $\mathrm{A} 12$ (A) and R20 (B). Data represent mean of 3 replicates \pm standard deviation; control vs. exposed cells, ${ }^{*} p<0.05$, Mann-Whitney $U$-test.

\section{Discussion}

$\mathrm{ABC}$ transporters are considered as gatekeepers in the gut, as they reduce the cellular burden of xenobiotics. ${ }^{17}$ Regulation of their expression has been extensively studied since it is one of the mechanisms leading to the multi-drug resistance phenotype in cancer cells. It occurs at both the transcriptional, posttranscriptional and post-translational levels. Our results show a global induction of MRP1, MRP2, MRP4 and BCRP genes in cells exposed to $\mathrm{TiO}_{2}$-NPs. This induction is detected at the mRNA expression level after $6 \mathrm{~h}$ of exposure and at the protein level following $48 \mathrm{~h}$ of exposure. This can be interpreted as a feedback loop, where cells react to the lack of protein by inducing mRNA expression; consequently at $48 \mathrm{~h}$, these ABC transporters are upregulated at the protein level while their mRNA expression has returned to its basal level. Coordinated regulation of these genes has already been demonstrated in the liver, in response to binding to their promoter region of nuclear receptors such as aryl hydrocarbon receptor, pregnane $\mathrm{X}$ receptor, constitutive androstane receptor, peroxisome proliferator-activated receptor $\alpha$ and nuclear factor-E2-related factor 2 (Nrf2). ${ }^{24,25} \mathrm{Nrf} 2$ is a transcription factor that is activated in response to oxidative stress. It regulates the expression of a battery of antioxidant genes; ${ }^{26}$ it has also been shown to positively regulate the expression of MRP1, MRP2, MRP4, MRP6, BCRP, MDR1. ${ }^{24,25,27}$ With respect to the misbalance of redox systems that we observe in this study, it is probable that Nrf2 is activated, which would explain the up-regulation of $\mathrm{ABC}$ transporters. This hypothesis is in adequacy with the results reported by others, from in vivo experiments. ${ }^{7}$ The consequences of up-regulation of $\mathrm{ABC}$ transporters in cells exposed to $\mathrm{TiO}_{2}$-NPs would be increased resistance to xenobiotic, but also to drugs such as chemotherapeutic agents, which is either beneficial or detrimental depending on the situation, i.e. normal life $v s$. therapeutic treatment.

Enterocytes express at their cell membrane a battery of transporters mediating the absorption of main dietary nutrients, i.e. sugars, amino acids, peptides, lipids, organic ions and a number of ions and solutes. In response to $\mathrm{TiO}_{2}-\mathrm{NP}$ exposure, we observe a global up-regulation of transporters involved in the absorption of most of these nutrients. This suggests a response to starvation caused by $\mathrm{TiO}_{2}-\mathrm{NP}$ exposure, and the necessity to increase cellular absorption of nutrients. For instance, increased expression of INSR would lead to increased fixation of insulin, and subsequent translocation of insulin-responsive vesicles (IRVs). The fusion of these vesicles with plasma membrane would increase GLUT-4 on the plasma membrane and finally enhance glucose absorption. We also report up-regulation of low-density lipoprotein receptor-related protein 1 (LRP1), which is a major component of IRVs. ${ }^{28}$ This down-regulation in intestinal cells has been associated with decreased IRVs migration toward cell surface. ${ }^{29}$ LRP1 up-regulation in $\mathrm{TiO}_{2}$-NP-exposed cells would thus be induced in response to the signal of IRVs migration for GLUT-4 presentation on cell surface, which would result from glucose starvation. In our results, up-regulation of GLUT-1 also suggests a 
response to glucose starvation, GLUT-1 being a facilitateddiffusion glucose transporter that is essential for the maintenance of high rates of glucose influx demanded by glycolysis. The insulin-responsive glucose absorption pathway has been identified as regulated by caveolin-1, an integral transmembrane protein of caveolae which protects the insulin receptor against degradation by the proteasome. ${ }^{30}$ In $\mathrm{TiO}_{2}$-NP exposed cells, CAV-1 mRNA expression is reduced; insulin-receptor would thus be less protected from degradation, which would be another argument supporting glucose starvation. Moreover CAV-1 is necessary for the migration of GLUT4 to cell surface, certainly in caveolae. ${ }^{30}$ This possible response to starvation may be induced by sequestration of nutrients on the surface of $\mathrm{TiO}_{2}$-NPs, as already suggested for carbon-based NPs, particularly nanotubes. ${ }^{31}$ Nanoparticle interaction with biomolecules is not limited to interaction with proteins, interaction with lipids and carbohydrates has also been demonstrated. ${ }^{32}$ This interaction may deplete exposure medium from these nutrients, thus inducing cell starvation.

Recent studies show that $\mathrm{TiO}_{2}$-NPs exert some toxic effects on undifferentiated ${ }^{12,13}$ or differentiated ${ }^{15}$ Caco-2 cells when they are prepared in serum-free medium. In the present study we evidence neither cytotoxicity nor DNA damage in Caco-2 cells exposed to $\mathrm{TiO}_{2}$-NPs. Discrepancies between these studies and our results can be explained by the surface coating of $\mathrm{TiO}_{2}$-NPs by the different protein coronas that form on NPs in presence and in absence of serum. As previously reported for $\mathrm{SiO}_{2}$ - and polystyrene-NPs the impact and cell uptake of NPs prepared in serum-containing culture medium is lower than that of NPs prepared in medium that does not contain serum. ${ }^{11,33}$ In absence of serum, NP adhesion on cell membranes and cellular uptake is higher and results in a different intracellular distribution: some NPs are observed "free" in cell cytosol, while in the presence of serum all the NPs are entrapped and sequestered in cytoplasmic vesicles that may avoid their interaction with active molecules in the cytosol. ${ }^{11,33}$ Our results, added to the data that we previously reported in A549 cells $^{34,35}$ and the results from the literature, suggest that this might also be the case for $\mathrm{TiO}_{2}$-NPs.

Next, our results evidence that intracellular accumulation of R20 is higher than accumulation of A12. This can either be due to more efficient cell uptake of R20, as compared to A12, or to higher exposure of cells to R20, as compared to A12. Again, uptake efficiency has been described as being driven by the protein corona that coats NPs, ${ }^{11,33}$ which defines their potency to interact with cell membranes and membrane transporters/receptors that may contribute to their internalization. It has also been shown to be governed by the crystalline structure of $\mathrm{TiO}_{2}$-NPs (for reviews see ref. 36, 37) and by their agglomeration state. ${ }^{38}$ Nevertheless, as the protein coronas on the surface of A12 and R20 have very close compositions, this parameter cannot explain differential accumulation of these NPs. Moreover A12 and R20 are covered with proteins, their mineral surface is thus hidden behind this corona and it is unlikely that the crystalline structure affects NP uptake by cells since the cell membrane is thus not directly exposed to anatase or a rutile mineral surface. Finally R20 are more agglomerated than A12 in exposure medium, this may trigger more efficient cell uptake since agglomeration state defines the route by which NPs are taken up in cells, some routes being more efficient and fast than others. Noteworthy, R20 being more agglomerated than A12, these NPs may more efficiently settle down on the cell layer, and consequently cell exposure to R20 may be higher than cell exposure to A12, as suggested in the ISDD model. ${ }^{39}$ Consequently, we consider that agglomeration state rather than the biological identity (i.e. the protein corona) or crystalline phase explains the higher accumulation of R20 in Caco- 2 cells that we observe. $\mathrm{TiO}_{2}-\mathrm{NP}$ accumulation increases between $6 \mathrm{~h}$ and $24 \mathrm{~h}$ of exposure, then decreases between $24 \mathrm{~h}$ and $48 \mathrm{~h}$ of exposure. This may be due to the release of NPs from cells, or more probably by NPs being split between daughter cells during cell division, as suggested by others. ${ }^{40,41}$

Finally, we show that both rutile and anatase $\mathrm{TiO}_{2}$-NPs cause major redox disorder in Caco-2 cells i.e. increased ROS and GSH contents, as well as inactivation of superoxide dismutase, but not catalase. GSH is a major molecular antioxidant in cells. Together with catalase, it is implicated in the elimination of hydrogene peroxide $\left(\mathrm{H}_{2} \mathrm{O}_{2}\right)$. Correlation of increased intracellular ROS content and increased glutathione production suggests that cells respond to ROS by inducing antioxidant response, thereby precluding the settling of oxidative stress. This hypothesis is supported by the observation of absence of further increase of ROS content between $6 \mathrm{~h}$ and $48 \mathrm{~h}$. However, inactivation of superoxide dismutase, which catalyses the dismutation of superoxide $\left(\mathrm{O}_{2}{ }^{-}\right)$to molecular oxygen $\left(\mathrm{O}_{2}\right)$ or hydrogen peroxide $\left(\mathrm{H}_{2} \mathrm{O}_{2}\right)$, may lead to accumulation of superoxide in NP-exposed cells. Superoxide is a byproduct of mitochondrial respiration; it is thus permanently produced in cells where it causes oxidative damage, such as mutagenesis and genomic instability, if not appropriately scavenged. Consequently our results prove that $\mathrm{TiO}_{2}$-NPs might indirectly cause oxidative damage in exposed cells, by avoiding the scavenging of deleterious $\mathrm{O}_{2}{ }^{-}$.

In summary, we show that $\mathrm{TiO}_{2}$-NPs, both anatase and rutile, induce up-regulation of a battery of SLC transporter and efflux pumps from the $\mathrm{ABC}$ transporter family in Caco-2 enterocytes, correlated to misbalance of cellular redox systems which may lead to accumulation of superoxide in exposed cells. However they do not cause overt mortality or damage to DNA.

\section{Experimental}

\subsection{Physico-chemical characterization of nanoparticles}

The used $\mathrm{TiO}_{2}$-NPs, termed $\mathrm{A} 12$ and R20, were produced in our laboratories. ${ }^{42}$ Their specific surface area was measured by the Brunauer, Emmett and Teller (BET) method, their crystalline phase by X-ray diffraction and their diameter was measured on transmission electron microscopy (TEM) images, as previously described. ${ }^{34,35}$ NPs suspensions $\left(10 \mathrm{mg} \mathrm{mL} \mathrm{mL}^{-1}\right)$ 
were prepared in ultrapure sterile water by pulsed probe sonication (Vibra Cell 75043, $20 \mathrm{kHz}$, Bioblock scientific, $28 \%$ amplitude, $1 \mathrm{~s}$ on/1 s off, $4^{\circ} \mathrm{C}$ ). Cells were exposed to $50 \mu \mathrm{g} \mathrm{mL}^{-1}$ of NPs diluted in cell culture medium containing $10 \%$ FBS. Their zeta potential was measured using a Zetasizer $3000 \mathrm{HS}$ and their agglomeration state was followed by dynamic light scattering (Malvern ZetaSizer 3000HS, Worcestershire, UK).

\subsection{Cell culture}

Caco-2 cells (ATCC HTB-37, passages from 39 to 45) were cultured in Dulbecco Modified Medium supplemented with 10\% $(\mathrm{v} / \mathrm{v})$ foetal bovine serum, $2 \mathrm{mM}$ L-glutamine, 1\% (v/v) nonessential amino acids, $50 \mathrm{UI} \mathrm{mL}{ }^{-1}$ penicillin and $50 \mu \mathrm{g} \mathrm{mL}$ streptomycin and maintained at $37^{\circ} \mathrm{C}, 5 \% \mathrm{CO}_{2}$. For synchrotron-radiation micro X-ray fluorescence (SR- $\mu \mathrm{XRF}$ ), TEM and qPCR experiments, cells were seeded at a density of 50000 cells $\mathrm{cm}^{-2}$ on Transwell-Clear ${ }^{\circledR}$ inserts (polyester, $0.4 \mu \mathrm{m}$ pores, Costar), grown to confluence and exposed to NPs at 21 days post-confluence. In this condition, the Caco-2 epithelium was well differentiated. ${ }^{16}$ For all other experiments, cells were exposed at sub-confluence in multi-well plates.

\subsection{Imaging}

4.3.1 Transmission electron microscopy. After $48 \mathrm{~h}$ of exposure to NPs of the apical pole of cells, transwell membranes on which cells were grown were rinsed with PBS, fixed in $2 \%$ glutaraldehyde in cacodylate buffer and in $1 \%$ osmium tetroxide, dehydrated through a graded series of ethanol and embedded in Epon resin. Ultra-thin sections were cut and stained with $1 \%$ uranyl acetate. They were observed on a JEOL 1200EX TEM operating at $80 \mathrm{kV}$.

4.3.2 Micro X-ray fluorescence imaging and X-ray absorption spectroscopy analysis. Samples embedded for TEM observation were also analysed by $\mathrm{SR}-\mu \mathrm{XRF}$, that detects trace element concentrations down to a few ppm, and enabled the mapping of their distribution on ID21 beam line (ESRF, Grenoble, France). Cross-sections $(3 \mu \mathrm{m})$ were cut and sandwiched between $4 \mu \mathrm{m}$-thick Ultralene® foils (SPEX SamplePrep). The X-ray beam was focussed to $0.2 \times 0.8 \mu \mathrm{m}^{2}(V \times H)$ by means of a Tungsten Fresnel Zone Plate lens. Ti, K, Ca, P/Os and $\mathrm{Cl}$ maps were acquired at fixed energy $(5.1 \mathrm{keV})$, with a $1 \times 1 \mu^{2}$ step. Data were processed using PyMCA. ${ }^{43}$ Cells were identified by mapping $\mathrm{P} / \mathrm{Os}$ distribution and $\mathrm{TiO}_{2}-\mathrm{NP}$ by mapping $\mathrm{Ti}$ distribution.

\subsection{Ti intracellular content quantification}

Intracellular Ti content was quantified using ICP-MS. After exposure, cells were thoroughly washed 4 times with PBS to remove particles that would be loosely bound to cell membrane. They were then harvested and counted. 360000 cells were suspended in $200 \mu \mathrm{L}$ of ultrapure water. These samples were dissolved by microwave-assisted acid decomposition, using conditions adapted from, ${ }^{44}$ in $10 \mathrm{~mL}$ of $48 \%$ (vol/vol) ultrapure grade $\mathrm{H}_{2} \mathrm{SO}_{4}$, for $30 \mathrm{~min}$ at $1100 \mathrm{~W}$. Samples were then diluted in ultrapure grade $1 \%(\mathrm{vol} / \mathrm{vol}) \mathrm{HNO}_{3}$ and analysed on a Nexion 300X ICP-MS (Perkin Elmer) equipped with a concentric nebulizer and operated in standard mode. Calibration curves were obtained from a certified ionic Ti solution. The concentrations of ${ }^{47} \mathrm{Ti},{ }^{48} \mathrm{Ti}$ and ${ }^{49} \mathrm{Ti}$ were analysed; final interpretation of the results was carried out on ${ }^{47} \mathrm{Ti}$ due to interference of $\mathrm{S}$ (from $\mathrm{H}_{2} \mathrm{SO}_{4}$ ) on ${ }^{48} \mathrm{Ti}$.

\subsection{NP impact assessment}

4.5.1 Cytotoxicity assay. Cells exposed to $0-200 \mu \mathrm{g} \mathrm{mL}^{-1}$ $\mathrm{TiO}_{2}$-NP for $24 \mathrm{~h}$, in cell culture medium containing FBS. Cell metabolic activity, reflecting NPs cytotoxicity, was assessed by using 3-(4,5-dimethylthiazol-z-yl)-2,5-diphenyl-tetrazotium bromide (MTT). After exposure, medium was replaced by $0.5 \mathrm{mg} \mathrm{mL}{ }^{-1} \mathrm{MTT}$; after $2 \mathrm{~h}$ at $37{ }^{\circ} \mathrm{C}$ formazan crystals were dissolved in DMSO. Plates were centrifuged at $200 \mathrm{~g}$ for $5 \mathrm{~min}$ to allow NPs to settle down, supernatants were then transferred to a new plate and absorbance was measured at $550 \mathrm{~nm}$. Interference of NPs with the MTT assay was monitored, as previously described. ${ }^{16}$

4.5.2 Genotoxicity assays. DNA strand breaks and alkalilabile sites were assessed via the alkaline comet assay. ${ }^{45}$ After exposure to NPs, cells were harvested, centrifuged at $200 \mathrm{~g}$ for 5 min and suspended in PBS. Cell suspension was mixed with $1 \%$ low melting point agarose and deposited onto agarosecoated slides. After solidification on ice, slides were immersed in cold lysis buffer $(2.5 \mathrm{M} \mathrm{NaCl}, 100 \mathrm{mM}$ EDTA, $10 \mathrm{mM}$ Tris, $10 \%$ DMSO, $1 \%$ Triton $\mathrm{X}-100$ ) for $1 \mathrm{~h}$, at room temperature, in the darkness. After alkaline unwinding (300 mM NAOH, $1 \mathrm{mM}$ EDTA, $\mathrm{pH}>13$ ), electrophoresis was processed at $0.7 \mathrm{~V} \mathrm{~cm}^{-1}$, $300 \mathrm{~mA}$ for $24 \mathrm{~min}$. Slides were neutralized with $0.4 \mathrm{M}$ Tris $\mathrm{pH}$ 7.5 and stained with ethidium bromide before observation. Comet analysis was achieved with Comet IV software (Perceptive instruments, Suffolk, UK).

4.5.3 Redox status assays. Redox status was first evaluated through measurements of intracellular ROS production, using 2',7'-dichlorodihydrofluorescein diacetate acetyl ester assay ( $\mathrm{H}_{2}$-DCF-DA, Invitrogen). ${ }^{46}$ After exposure to NPs, cells were washed and incubated $30 \mathrm{~min}$ at $37^{\circ} \mathrm{C}$ with $80 \mu \mathrm{M}$ H2DCFDA, then harvested by scraping. Fluorescence intensity was measured with excitation at $480 \mathrm{~nm}$ and emission at $530 \mathrm{~nm}$ (Molecular Devices Gemini X fluorescence spectrophotometer) and normalized with respect to the protein concentration. Then reduced glutathione (GSH) content in cells, superoxide dismutase (SOD) and catalase (CAT) activities were evaluated as described earlier. ${ }^{47}$ After exposure, cells were rinsed with PBS, lysed and their volume was normalized with respect to protein content. GSH was measured via its oxidation by 5,5'-dithiobis(2-nitrobenzoic acid) (DTNB). Catalase activity was determined by following the disappearance of $\mathrm{H}_{2} \mathrm{O}_{2}$ at $240 \mathrm{~nm}$ and comparing to a standard. SOD activity was measured through the inhibition by endogenous SOD of nicotinamide adenine dinucleotide oxidation by superoxide radical anions, produced in situ with $10 \mathrm{mM} \beta$-mercaptoethanol. One unit of SOD activity is defined as the amount causing 50\% inhibition of $\mathrm{NADH}$ oxidation in this condition. 
4.5.4 Real-time polymerase chain reaction (RT-qPCR). Gene expression profiles were analysed by RT-qPCR. RNA was isolated from cells using GenElute ${ }^{\mathrm{TM}}$ mammalian total RNA kit (Sigma Aldrich). The A260/A280 ratio ranged between 1.9 and 2 , attesting the purity of extracted RNA. $1 \mu \mathrm{g}$ of RNA was converted into cDNA with random primers $(0.4 \mu \mathrm{M})$ using the RT2 first strand kit (Superarray Bioscience Corporation, Frederick, USA). Quantitative PCR was performed in a MX3005P multiplex quantitative PCR system (Stratagene) using MESA Blue qPCR Mastermix for SYBR Assay Low ROX. Relative expression values were calculated as $2^{-\Delta \Delta C_{\mathrm{t}}}$, where $\Delta C_{\mathrm{t}}$ is the difference between the cycle threshold $\left(C_{\mathrm{t}}\right)$ values for target and reference, which is then divided by $\Delta C_{\mathrm{t}}$ of the calibrator (housekeeping) gene in order to obtain $\Delta \Delta C_{\mathrm{t}}$ values. ${ }^{48} \mathrm{~S} 18$ and GAPDH were chosen as housekeeping genes for normalization and amplified in triplicate for each assay. Variability in the expression of these housekeeping genes among the various conditions was assessed by Bestkeeper, an Excel-based pairwise mRNA correlation tool. ${ }^{49}$ RNA level modulation of target genes was computed using the Relative Expression Software Tool (REST) ${ }^{50}$ based on $C_{\mathrm{t}}$ comparison. Data are expressed as percentages of the corresponding control \pm standard deviation.

4.5.5 Quantification of protein expression. Protein expression was quantified by western blot. We used 4 replicates of each exposure conditions and controls. Total proteins were extracted and $20 \mu \mathrm{g}$ of protein was deposited on 3 independent stain-free $\mathbf{7 . 5 \%}$ polyacrylamide gels (Biorad), which migrated at $200 \mathrm{~V}$ for $40 \mathrm{~min}$. After transfer on nitrocellulose membranes, ABC transporter proteins were blotted using specific antibodies (MDR1: Abcam ab170904, 1/2500; MRP1: Abcam ab24102, 1/500; MRP2: Abcam ab3373, 1/200; BCRP: Abcam ab108312, 1/2500). For each of the 4 replicates, on each gel, the intensity of the specific band was normalized with respect to total protein content of the lane. Then for each replicate, the normalized intensities of exposed cells were divided by the normalized intensities of unexposed cells. Average and standard deviation of these normalized expressions are presented.

\subsection{Statistical analyses}

Non-parametric one-way analysis of variance on ranks approach (Kruskal-Wallis) was performed using the Statistica 7.1 software (Statsoft, Chicago, USA). Paired comparisons were run using Mann-Whitney $U$-tests and results were considered statistically significant when $p<0.05$.

\section{Conclusions}

Our results evidenced that agglomerated $\mathrm{TiO}_{2}-\mathrm{NPs}$, both anatase and rutile, coated with serum proteins, induce no cytotoxicity or genotoxicity but misbalance the redox status of Caco-2 enterocytes. Independently of their crystalline phase, these NPs induce general up-regulation of genes encoding efflux pumps from the ABC transporter family as well as transporters involved in nutrient uptake. This suggests a cellular response to nutrient starvation and oxidative stress. Finally, all these results may pave the way to future studies related to the impact of $\mathrm{TiO}_{2}$-NPs on the gastro-intestinal epithelium, among them perturbation of nutrient and drug absorption, as well as xenobiotic efflux. Note that these experiments have been conducted on in vitro cell models, exposed to high concentrations of $\mathrm{TiO}_{2}$-NPs. They should now be completed with experiments at lower doses, upon chronic exposure, to real-life food additive.

\section{Acknowledgements}

This work was funded by the region Ile de France through the framework C'nano Ile de France (NanoDIG project), by INERIS in the frame of the post-Grenelle program (NANOTRANS project) by ANSES (NanoGut project) and ADEME and by the CEA Toxicology program (INAGINATOX project). It is a contribution to the Labex Serenade ( $\mathrm{n}^{\circ}$ ANR-11-LABX-0064) funded by the «Investissements d'Avenir» French Government program of the French National Research Agency (ANR) through the $A^{*}$ MIDEX project ( ${ }^{\circ}$ ANR-11-IDEX-0001-02). The authors would like to thank the European Synchrotron Radiation Facility for provision of synchrotron radiation facilities at ID21. We thank D. Jaillard (CCME, Orsay, France) and J. Delaroche (GIN, Grenoble, France) for helping in ultramicrotomy, S. Motellier and K. Lhaute for the optimization of sample preparation for ICP-MS and A. Mabondzo (CEA, Saclay, France) for helping in RT-qPCR experiments.

\section{Notes and references}

1 Q. Chaudhry, M. Scotter, J. Blackburn, B. Ross, A. Boxall, L. Castle, R. Aitken and R. Watkins, Food Addit. Contam., Part A, 2008, 25, 241.

2 US-EPA, National Center for Environmental AssessmentRTP division, Office of Research and Development, U.S. Environmental Protection Agency, Research Triangle Park, NC., November 2010, p. 222.

3 A. Weir, P. Westerhoff, L. Fabricius, K. Hristovski and N. von Goetz, Environ. Sci. Technol., 2012, 46, 2242.

4 J. J. Powell, N. Faria, E. Thomas-McKay and L. C. Pele, J. Autoimmun., 2010, 34, 21.

5 Y. Yang, K. Doudrick, X. Bi, K. Hristovski, P. Herckes, P. Westerhoff and R. Kaegi, Environ. Sci. Technol., 2014, 48, 6391.

6 I. L. Bergin and F. A. Witzmann, Int. J. Biomed. Nanosci. Nanotechnol., 2013, 3, 054515.

7 S. Gui, B. Li, X. Zhao, L. Sheng, J. Hong, X. Yu, X. Sang, Q. Sun, Y. Ze, L. Wang and F. Hong, J. Agric. Food Chem., 2013, 61, 8959.

8 S. Gui, Z. Zhang, L. Zheng, Y. Cui, X. Liu, N. Li, X. Sang, Q. Sun, G. Gao, Z. Cheng, J. Cheng, L. Wang, M. Tang and F. Hong, J. Hazard. Mater., 2011, 195, 365.

9 X. Zhao, Y. Ze, G. Gao, X. Sang, B. Li, S. Gui, L. Sheng, Q. Sun, J. Cheng, Z. Cheng, R. Hu, L. Wang and F. Hong, PLoS One, 2013, 8, 2. 
10 A. Lesniak, A. Campbell, M. P. Monopoli, I. Lynch, A. Salvati and K. A. Dawson, Biomaterials, 2010, 31, 9511.

11 A. Lesniak, F. Fenaroli, M. P. Monopoli, C. Aberg, K. A. Dawson and A. Salvati, ACS Nano, 2012, 6, 5845.

12 K. Gerloff, C. Albrecht, A. W. Boots, I. Forster and R. P. Schins, Nanotoxicology, 2009, 3, 355.

13 K. Gerloff, I. Fenoglio, E. Carella, J. Kolling, C. Albrecht, A. W. Boots, I. Forster and R. P. Schins, Chem. Res. Toxicol., 2012, 25, 646.

14 I. De Angelis, F. Barone, A. Zijno, L. Bizzarri, M. T. Russo, R. Pozzi, F. Franchini, G. Giudetti, C. Uboldi, J. Ponti, F. Rossi and B. De Berardis, Nanotoxicology, 2013, 1, early online.

15 B. A. Koeneman, Y. Zhang, P. Westerhoff, Y. Chen, J. C. Crittenden and D. G. Capco, Cell Biol. Toxicol., 2009, 26, 225.

16 E. Brun, F. Barreau, G. Veronesi, B. Fayard, S. Sorieul, C. Chaneac, C. Carapito, T. Rabilloud, A. Mabondzo, N. Herlin-Boime and M. Carriere, Part. Fibre Toxicol., 2014, 11, 1743.

17 E. M. Leslie, R. G. Deeley and S. P. Cole, Toxicol. Appl. Pharmacol., 2005, 204, 216.

18 X. Alvarez-Hernandez, G. M. Nichols and J. Glass, Biochim. Biophys. Acta, 1991, 18, 205.

19 J. R. Gurr, A. S. Wang, C. H. Chen and K. Y. Jan, Toxicology, 2005, 213, 66.

20 V. H. Grassian, P. T. O'Shaughnessy, A. Adamcakova-Dodd, J. M. Pettibone and P. S. Thorne, Environ. Health Perspect., 2007, 115, 397.

21 Z. J. Deng, M. Liang, I. Toth, M. J. Monteiro and R. F. Minchin, ACS Nano, 2012, 6, 8962.

22 M. Lundqvist, J. Stigler, T. Cedervall, T. Berggard, M. B. Flanagan, I. Lynch, G. Elia and K. Dawson, ACS Nano, 2011, 5, 7503.

23 G. Veronesi, E. Brun, B. Fayard, M. Cotte and M. Carriere, Appl. Phys. Lett., 2012, 100.

24 J. M. Maher, X. Cheng, A. L. Slitt, M. Z. Dieter and C. D. Klaassen, Drug Metab. Dispos., 2005, 33, 956.

25 J. M. Maher, M. Z. Dieter, L. M. Aleksunes, A. L. Slitt, G. Guo, Y. Tanaka, G. L. Scheffer, J. Y. Chan, J. E. Manautou, Y. Chen, T. P. Dalton, M. Yamamoto and C. D. Klaassen, Hepatology, 2007, 46, 1597.

26 P. Shelton and A. K. Jaiswal, FASEB J., 2013, 27, 414.

27 L. Ji, H. Li, P. Gao, G. Shang, D. D. Zhang, N. Zhang and T. Jiang, PLoS One, 2013, 8, 2013.

28 K. V. Kandror and P. F. Pilch, Traffic, 2011, 12, 665.

29 M. P. Jedrychowski, C. A. Gartner, S. P. Gygi, L. Zhou, J. Herz, K. V. Kandror and P. F. Pilch, J. Biol. Chem., 2010, 285, 104.
30 A. W. Cohen, T. P. Combs, P. E. Scherer and M. P. Lisanti, Am. J. Physiol.: Endocrinol. Metab., 2003, 285, E1151.

31 A. Casey, E. Herzog, F. M. Lyng, H. J. Byrne, G. Chambers and M. Davoren, Toxicol. Lett., 2008, 179, 78.

32 M. P. Monopoli, C. Aberg, A. Salvati and K. A. Dawson, Nat. Nanotechnol., 2012, 7, 779.

33 A. Lesniak, A. Salvati, M. J. Santos-Martinez, M. W. Radomski, K. A. Dawson and C. Aberg, J. Am. Chem. Soc., 2013, 135, 1438.

34 M. L. Jugan, S. Barillet, A. Simon-Deckers, N. Herlin-Boime, S. Sauvaigo, T. Douki and M. Carriere, Nanotoxicology, 2012, 6, 501.

35 A. Simon-Deckers, B. Gouget, M. Mayne-L'hermite, N. Herlin-Boime, C. Reynaud and M. Carriere, Toxicology, 2008, 253, 137.

36 Z. Magdolenova, A. Collins, A. Kumar, A. Dhawan, V. Stone and M. Dusinska, Nanotoxicology, 2013, 2013, 20.

37 H. Shi, R. Magaye, V. Castranova and J. Zhao, Part. Fibre Toxicol., 2013, 10, 1743.

38 Z. Magdolenova, D. Bilanicova, G. Pojana, L. M. Fjellsbo, A. Hudecova, K. Hasplova, A. Marcomini and M. Dusinska, J. Environ. Monit., 2012, 14, 455.

39 P. M. Hinderliter, K. R. Minard, G. Orr, W. B. Chrisler, B. D. Thrall, J. G. Pounds and J. G. Teeguarden, Part. Fibre Toxicol., 2010, 7, 36.

40 C. Aberg, J. A. Kim, A. Salvati and K. A. Dawson, EPL, 2013, 101.

41 J. A. Kim, C. Aberg, A. Salvati and K. A. Dawson, Nat. Nanotechnol., 2011, 7, 62.

42 B. Pignon, H. Maskrot, Y. Leconte, S. Coste, C. Reynaud, N. Herlin-Boime, M. Gervais, V. Guyot Ferreol, T. Pouget and J. F. Tranchant, Eur. J. Inorg. Chem., 2008, 6, 883.

43 V. A. Sole, E. Papillon, M. Cotte, P. Walter and J. Susini, Spectrochim. Acta, Part A, 2007, 62, 63.

44 F. E. Smith and E. A. Arsenault, Talanta, 1996, 43, 1207.

45 N. P. Singh, M. T. McCoy, R. R. Tice and E. L. Schneider, Exp. Cell Res., 1988, 175, 184.

46 Y. Oyama, A. Hayashi, T. Ueha and K. Maekawa, Brain Res., 1994, 635, 113.

47 S. Barillet, M.-L. Jugan, M. Laye, Y. Leconte, N. HerlinBoime, C. Reynaud and M. Carrière, Toxicol. Lett., 2010, 198, 324.

48 K. J. Livak and T. D. Schmittgen, Methods, 2001, 25, 402.

49 M. W. Pfaffl, A. Tichopad, C. Prgomet and T. P. Neuvians, Biotechnol. Lett., 2004, 26, 509.

50 M. W. Pfaffl, G. W. Horgan and L. Dempfle, Nucleic Acids Res., 2002, 30, e36. 